慶應義塾大学学術情報リポジトリ

Keio Associated Repository of Academic resouces

\begin{tabular}{|c|l|}
\hline Title & $\begin{array}{l}\text { New synthesis of 4-methyl-2-methylamino-5-(N-methylthiocarbamoyl) thiazole by thermal } \\
\text { isomerization }\end{array}$ \\
\hline Sub Title & \multicolumn{1}{|c|}{} \\
\hline Author & $\begin{array}{l}\text { 山本, 有一(Yamamoto, Yuichi) } \\
\text { 与田, 玲子( Yoda, Reiko) } \\
\text { 田村, 千尋( Tamura, Chihiro) }\end{array}$ \\
\hline Publisher & 共立薬科大学 \\
\hline Publication year & 1976 \\
\hline Jtitle & $\begin{array}{l}\text { 共立薬科大学研究年報 (The annual report of the Kyoritsu College of } \\
\text { Pharmacy). No.21 (1976. ),p.94- 95 }\end{array}$ \\
\hline JaLC DOI & \\
\hline Abstract & \\
\hline Notes & 抄録 \\
\hline Genre & Technical Report \\
\hline URL & $\begin{array}{l}\text { https://koara.lib.keio.ac.jp/xoonips/modules/xoonips/detail.php?koara_id=AN00062898-0000002 } \\
1-0094\end{array}$ \\
\hline
\end{tabular}

慶應義塾大学学術情報リポジトリ(KOARA)に掲載されているコンテンツの著作権は、それぞれの著作者、学会または出版社/発行者に帰属し、その権利は著作権法によって 保護されています。引用にあたっては、著作権法を遵守してご利用ください。

The copyrights of content available on the KeiO Associated Repository of Academic resources (KOARA) belong to the respective authors, academic societies, or publishers/issuers, and these rights are protected by the Japanese Copyright Act. When quoting the content, please follow the Japanese copyright act. 


\title{
NEW SYNTHESIS OF 4-METHYL-2-METHYLAMINO-5-
}

\section{(N-METHYLTHIOCARBAMOYL) THIAZOLE BY THERMAL ISOMERIZATION}

\author{
YUICHI YAMAMOTO, REIKo YODA, and CHIHIRO 'TAMURA
}

山本有一, 与田玲子, 田村千赫

The reaction of 4-methyl-2-methylamionthiazole (I) with methyl isothiocyanate in toluene in the presence of pyridine gave the crystals of $\mathrm{mp} 56-57^{\circ} \mathrm{C}$ (IIa) having $\mathrm{Rf}$ value of 0.75 (2-propanol: ether, $1: 1$ ), ${ }_{\text {max }}$ (2-propanol) 260 (sh.), $291 \mathrm{~nm}$ ( $\varepsilon=$ 19500) and yellow crystals of $\mathrm{mp} 249-250^{\circ} \mathrm{C}$ (IIIa) having $\mathrm{Rf}$ value of $0.53, \lambda_{\max }(2-$ propanol) 294 $(\varepsilon=6310), 340 \mathrm{~nm}(\varepsilon=11500)$.

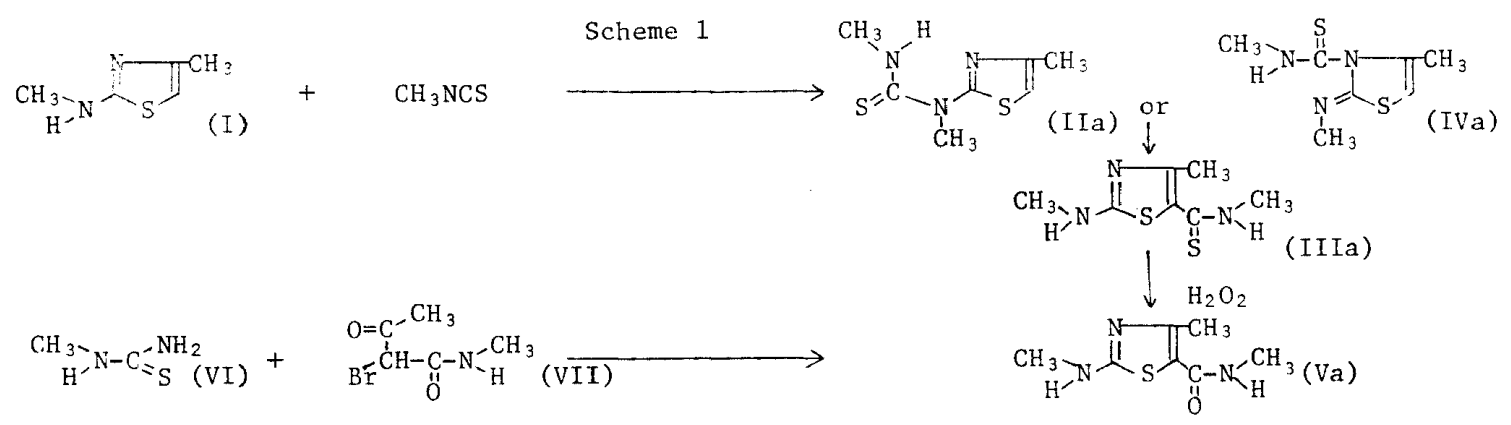

The elemental analysis and mass spectral data (MW 201) gave a molecular formula of $\mathrm{C}_{7} \mathrm{H}_{11} \mathrm{~N}_{3} \mathrm{~S}_{2}$ for both (IIa) and (IIIa), isomeric to each other. The thermal isomerization of (IIa) in pyridine gave (IIIa). As the spectral interpretation could not differentiate 1,3-dimethyl-1-(4-methylthiazol-2-yl) thiourea (IIa) and 4-methyl2-methylimino-3-(N-methylthiocarbamoyl)-4-thiazoline (IVa), the structure of (IIa) was established by an $\mathrm{X}$-ray analysis.

The NMR spectrum ( $\mathrm{d}_{6}-\mathrm{DMSO}$ ) of (IIIa) showed signals at $\delta 2.29$ (singlet, $3 \mathrm{H}$, $=\mathrm{C}-\mathrm{CH}_{3}$ ), 3.10 (doublet, $3 \mathrm{H}, \mathrm{J}=5.0 \mathrm{~Hz}$, singlet after $\mathrm{D}_{2} \mathrm{O}$ exchange, singlet after irradiation at $9.06,-\mathrm{NH}$ ), 2.28 (doublet, $3 \mathrm{H}, \mathrm{J}=5.0 \mathrm{~Hz}$, singlet after $\mathrm{D}_{2} \mathrm{O}$ exchange, singlet after irradiation at $7.86,-\underline{N H}$ ) 9.06 (broad, $1 \mathrm{H}$, disappeared after $\mathrm{D}_{2} \mathrm{O}$ exchange, $-\mathrm{CH}_{3}-\underline{\mathrm{NH}}-$ ), and $7.86 \delta$ (broad, $1 \mathrm{H}$, disappeared after $\mathrm{D}_{2} \mathrm{O}$ exchange, $\mathrm{CH}_{3} \mathrm{NH}-$ ). The structure of (IIIa) was estimated from the appearance of two doublets for $\underline{\mathrm{C}}_{3} \mathrm{NH}$ and the absence of a singlet due to $\mathrm{H}$ at position 5 .

The product obtained by the alkaline $\mathrm{H}_{2} \mathrm{O}_{2}$ treatment of (IIIa) was identified with the product, 4-methyl-2-methylamino-5-(N-methylcarbamoyl)thiazole (Va) from the reaction of (VI) and (VII), by the mixed $\mathrm{mp}$, and from UV, Mass and NMR spectral comparison.

* 本報告は Chemistry Letters, 1147-1148（1975）に発表。 
Table I shows the result of monitoring of the thermal rearrangement of (IIa) to (IIIa), by measuring the absorption at $340 \mathrm{~nm}$ due to (IIIa) every $2.5 \mathrm{hr}$ in a different solvent. This result suggests that an essential factor in the rearrangement is the presence of pyridine.

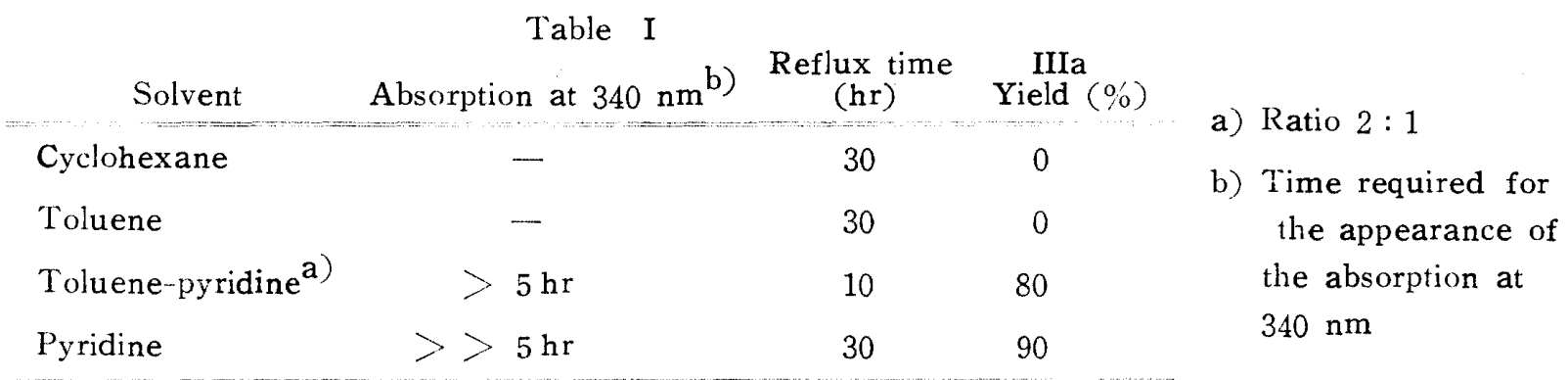

